\title{
HUBUNGAN KEBIASAAN MEROKOK DI DALAM RUMAH DENGAN KEJADIAN PNEUMONIA PADA ANAK USIA 1-4 TAHUN
}

\author{
Nuniek Tri Wahyuni, Heni Fa'riatul Aeni, Muhammad Azizudin \\ STIKes Cirebon JI. Brigjend Dharsono No.12 B Cirebon, 082117557147 \\ nuniek.triwahyuni@yahoo.com
}

\begin{abstract}
ABSTRAK
Pneumonia merupakan penyebab dari 15\% kematian pada balita. Keberadaan anggota keluarga yang merokok di dalam rumah merupakan salah satu faktor penyebab terjadinya masalah kesehatan pada sistem pernafasan khususnya Pneumonia pada anak. Tujuan penelitian ini adalah untuk mengetahui hubungan kebiasaan merokok di dalam rumah dengan kejadian Pneumonia pada anak usia 1-4 tahun. Jenis penelitian ini adalah penelitian analitik dengan pendekatan cross sectional. Populasi penelitian ini adalah anggota keluarga yang memiliki anak usia 1-4 tahun yang terkena Pneumonia sebanyak 110 dengan jumlah sampel 86 responden menggunakan accidental sampling. Pengumpulan data diperoleh dengan menggunakan kuesioner dan dianalisis secara statistik menggunakan uji Chi Square. Berdasarkan hasil uji statistik dari 86 responden yang memiliki keberadaan orang yang merokok di dalam rumah sebanyak 52 orang (60,47\%) sedangkan keberadaan orang yang tidak merokok di dalam rumah sebanyak 34 (39,53\%). Responden dengan kategori mengalami Pneumonia sebanyak 75 orang $(87,21 \%)$, yang mengalami Pneumonia berat sebanyak 7 orang (8,14\%) dan yang mengalami Pneumonia sangat berat sebanyak 4 orang $(4,63 \%)$ dengan $P$ value $=0,016(<0,05)$. Terdapat hubungan kebiasaan merokok dengan kejadian Pneumonia pada anak usia 1-4 tahun.
\end{abstract}

Kata kunci : kebiasaan merokok; pneumonia; anak

\section{CORRELATION BETWEEN SMOKING HABITS AT HOME AND THE INCIDENT OF PNEUMONIA AMONG CHILDREN AGED 1-4 YEARS}

\begin{abstract}
Pneumonia is the cause of $15 \%$ of deaths in children under five. The presence of family members who smoke in the house is one of the causal factors of health problems in the respiratory system, especially pneumonia among children. This study was aimed to determine the correlation between smoking habits at home and the incidence of pneumonia among children aged 1-4 years. This was an analytic study with cross sectional approach. The population of this study were family members who had children aged 1-4 years with pneumonia as many as 110 people. The number of samples was taken through the Slovin sample size formula totally 86 respondents and the determination of the samples used Accidental Sampling. Data were collected using a questionnaire and analyzed statistically using the Chis Square test. Based on the results of statistical tests, it was revealed that of 86 respondents, 52 people (60.47\%) had the presence of people who smoked in the house while 34 (39.53\%) did not have had the presence of people who smoked in the house. 75 respondents (87.21\%) had pneumonia, 7 people experienced severe pneumonia (8.14\%) and 4 people experienced very severe pneumonia (4.63\%). Chi Square test results obtained a $P$ value $=0.016(<0.05)$, which meant that there is a relationship between smoking habit at home and the incidence of pneumonia among children aged 1-4 years.
\end{abstract}

Keywords: Smoking habit; pneumonia; children 


\section{LATAR BELAKANG}

Pneumonia masih menjadi penyakit terbesar penyebab kematian anak dan juga penyebab kematian pada banyak kaum lanjut usia di dunia. Pneumonia pada balita paling sering disebabkan oleh virus pernafasan (Respiratory Syncytial Virus, adenovirus, virus parainfluenza, virus influenza) dan puncaknya terjadi pada usia 2-3 tahun. Sedangkan pada anak usia sekolah paling sering disebabkan bakteri Mycoplasma Pneumoniae. Bakteri penyebab Pneumonia yang paling sering adalah Streptococcus Pneumoniae (pneumokokus), Hemophilus influenzae type $b$ (Hib) dan Staphylococcus aureus (Saureus)(Oktaviani, 2018).

Menurut Kemenkes 2016 Pneumonia merupakan penyakit infeksi terbesar penyebab kematian pada anak-anak di dunia. Pneumonia juga merupakan penyebab dari 15\% kematian pada balita, yaitu diperkirakan sekitar 922.000 balita di tahun 2015 meninggal. Pneumonia menyerang semua umur di tiap wilayah, namun banyak yang terjadi di Asia Selatan dan Afrika Sub-Sahara. Di Indonesia sendiri Pneumonia termasuk penyakit yang menyebabkan kematian pada anak. Pada tahun 2015 terjadi peningkatan kejadian Pneumonia menjadi $63,45 \%$ dibandingkan pada tahun sebelumnya dimana kejadian Pneumonia hanya berkisar antara 20\%-30\% (Putri, 2017).

Indonesia merupakan Negara dengan konsumsi rokok terbesar di dunia, berada pada peringkat ketiga setelah China dan India. Sedangkan di tingkat ASEAN Indonesia berada pada peringkat pertama sebanyak $(46,16 \%)$ dan persentase terkecil ada di Negara Brunei $(0,04 \%)$ (Kemenkes, 2013).

Berdasarkan jenis kelamin prevalensi merokok di Indonesia pada laki-laki lebih tinggi dari pada perempuan. Pada tahun 2013 prevalensi merokok pada laki-laki dewasa meningkat dari $65,8 \%$ tahun 2010 menjadi $66 \%$ (Kemenkes, 2018b).

Berdasarkan penelitian yang dilakukan oleh Retna Puspita yang berjudul "gambaran karakteristik kejadian Pneumonia pada balita di puskesmas Wanandadi Kabupaten Banjarnegara 2014", menyatakan bahwa dari 26 responden sebagian besar balita usia 1-4 tahun dengan hasil: pendidikan menengah ibu sebanyak 17 (65\%), ventilasi rumah sesuai dengan luas bangunan 15 responden (58\%), menggunakan bahan bakar kayu bakar 16 responden (38\%), tidak memberikan ASI eksklusif pada balita 19 responden (73\%) dan keberadaan anggota keluarga yang merokok 23 responden (88\%) (Puspita, 2015).

Hasil dari penelitian Almer Aprilioza, Dadi S Argadireza, Yudi Feriandi dengan judul "hubungan kebiasaan merokok pada orang tua dengan kejadian pneumonia pada balita di wilayah kerja Puskesmas Plered" dari 84 balita terdapat 43 balita yang mengalami Pneumonia dengan orang tua yang memiliki kebiasaan merokok $(95,6 \%)$ dan 2 balita dengan orang tua yang tidak memiliki kebiasaan merokok $(4,4 \%)$. Sedangkan balita yang tidak mengalami Pneumonia berjumlah 32 balita yang memiliki orang tua dengan kebiasaan merokok $(82,1 \%)$ dan 7 balita dengan orang tua yang tidak memiliki kebiasaan merokok (19,9\%). Didapatkan hasil uji statistic dengan $P$ value $=$ $0,049(<0,5)$ sehingga dapat disimpulkan terdapat hubungan kebiasaan merokok orang tua dengan kejadian pneumonia pada balita. (Aprilioza, Almer. Argadireza, Dadi S. Feriandi, 2015). Penelitian ini hanya melihat keberadaan anggota keluarga yang memiliki kebiasaan merokok atau tidak, tanpa melihat kebiasaan merokoknya di dalam rumah atau bukan.

Berdasarkan data Riskesda tahun 2018, Jawa Barat mendapatkan urutan ke empat tertinggi di Indonesia sebesar 2.5\% angka kejadian pneuomia pada balita (Kemenkes, 2018a). Menurut Dinkes Kabupaten Cirebon angka kejadian Pneumonia di Kabupaten Cirebon mencapai 3000 lebih pada anak $0-<5$ tahun. Yang memiliki kejadian Pneumonia pada anak usia $1-<5$ yang paling tinggi yaitu terdapat di Wilayah Kerja UPTD Puskesmas Mundu (P2P, 2019).

Berdasarkan studi pendahuluan yang dilakukan di UPTD Puskesmas Mundu Kabupaten Carebon pada tanggal 2 maret 2020, menyatakan bahwa ada 110 anak yang menderita Pneumonia. Angka perokok aktif yang merokok di dalam rumah di wilayah kerja UPTD Puskesmas Mundu Kabupaten Cirebon masih tinggi, yaitu sekitar 6479 orang yang memiliki kebiasaan merokok di dalam rumah. 
Hal ini menunjukan kekhawatiran bagi kesehatan anak-anak dan keluarga yang lainnya. Tujuan penelitian ini adalah untuk mengetahui hubungan kebiasaan merokok di dalam rumah dengan kejadian Pneumonia pada anak usia 1-4 tahun.

\section{METODE}

Penelitian ini dilakukan dengan menggunakan pendekatan kuantitatif yakni data yang berhubungan dengan angka-angka, baik yang diperoleh dari hasil pengukuran, maupun dari nilai suatu data yang diperoleh. Sedangkan untuk desain penelitian menggunakan cross sectional yang merupakan studi epidemiologi yang mengukur beberapa variabel sekaligus (Hidayat, 2013). Penelitian ini dilakukan di wilayah kerja UPTD Puskesmas Mundu Kabupaten Cirebon pada bulan Mei tahun 2020. Populasi pada penelitian ini adalah anak usia 14 tahun yang mengalami Pneumonia di wilayah kerja UPTD Puskesmas Mundu kabupaten Cirebon dengan jumlah 110 anak. Sampel yang diambil dalam penelitian ini menggunakan metode accidental sampling. Besar sampel ditentukan dengan menggunakan rumus Slovin dan diperoleh sebanyak 86 responden yang diambil secara accidental sampling. Accidental Sampling adalah metode penentuan sampel tanpa sengaja (accidental) ini, peneliti mengambil sampel yang kebetulan ditemuinya pada saat dilakukan penelitian (Sugiyono, 2016).

Kriteria Inklusi dalam penelitian ini adalah anak usia 1-4 tahun, Masih sebagai pasien pneumonia, terdapat anggota keluarga yang merokok. Instrument penelitian yang digunakan berupa kuesioner. Variabel independen dalam penelitian ini adalah kebiasaan merokok di dalam rumah dan variabel dependennya adalah kejadian Pneumonia pada anak usia 1-4 tahun di wilayah kerja UPTD Puskesmas Mundu kabupaten Cirebon 2020. Pengumpulan data diperoleh dengan menggunakan kuesioner yang diambil langsung dari responden yaitu anggota keluarga yang memiliki anak yang menderita Pneumonia yang berada di wilayah kerja UPTD Puskesmas Mundu Kabupaten Cirebon dan data yang diperoleh dari studi pendahuluan yang berasal dari data Dinas Kesehatan Kabupaten. Analisis penelitian ini menggunakan uji statistik yaitu Chi square dengan alternatif Pearson Chi-Square dengan tingkat kepercayaan $5 \%$.

\section{HASIL}

Analisa univariat dilakukan dengan maksud meringkas sekumpulan data hasil pengukuran sedemikian rupa sehingga kesimpulan dari data berubah menjadi informasi yang berguna. Data univariat dalam penelitian ini terdiri atas karakteristik responden, kebiasaan merokok di dalam rumah, dan kejadian Pneumonia pada usia 1-4 tahun.

\section{Karakteristik Responden}

Hasil penelitian mengenai karakteristik responden diperoleh data mengenai pendidikan orang tua responden, jenis kelamin anak, dan usia anak.

Tabel 1. Distribusi Frekuensi Karakteristik Responden ( $n=86$ )

\begin{tabular}{lcc}
\hline Kategori & $\begin{array}{c}\text { Jumlah } \\
(\mathrm{n})\end{array}$ & $\begin{array}{c}\text { Persentas } \\
\mathrm{e}(\%)\end{array}$ \\
\hline $\begin{array}{l}\text { Pendidikan orang } \\
\text { responden }\end{array}$ & & \\
$\quad$ SD & 72 & 83,72 \\
SMP & 13 & 15,11 \\
SMA & 1 & 1,17 \\
Jenis kelamin anak & & \\
$\quad$ Perempuan & 40 & 46,51 \\
$\quad$ Laki-laki & 46 & 53,49 \\
Usia anak & & \\
1 tahun & 54 & 62,79 \\
2 tahun & 24 & 27,90 \\
3 tahun & 6 & 6,98 \\
4 tahun & 2 & 2,33 \\
\hline
\end{tabular}

Tabel 1 menunjukkan bahwa dari 86 responden sebagian besar pendidikan orang tuanya adalah SD sebanyak 72 (83,72\%), berdasarkan jenis kelamin lebih dari setengahnya adalah laki-laki sebanyak 46 (53,49\%), dan berdasarkan usia anak sebagian besar berusia 1 tahun sebanyak 54 (62,79\%).

Analisa bivariat berfungsi untuk mengetahui hubungan antara kebiasaan merokok di dalam rumah kejadian Pneumonia pada anak usia 1-4 tahun. Tabel 2 menunjukkan hasil analisis hubungan kebiasaan merokok di dalam rumah 
dengan kejadian Pneumonia pada anak usia 14 tahun diperoleh dari 34 anak dengan tidak ada kebiasaan merokok di dalam rumah, yang mengalami Pneumonia sebanyak 34 anak $(100 \%)$ yang mengalami Pneumonia berat dan sangat berat sebanyak 0 anak $(0 \%)$ dengan hasil $p$ value $=0,016$. Dari uji statistik dengan Chi Square didapatkan hasil dimana nilai $p=$
$0,016(<0,05)$. Hal ini menyimpulkan bahwa $\mathrm{H}_{0}$ ditolak atau $\mathrm{H}_{\mathrm{a}}$ diterima menunjukkan bahwa ada hubungan kebiasaan merokok di dalam rumah dengan kejadian Pneumonia pada anak usia 1-4 tahun di wilayah kerja UPTD Puskesmas Mundu Kabupaten Cirebon Tahun 2020.

Tabel 2 Hubungan Kebiasaan merokok di dalam rumah dengan kejadian Pneumonia pada Anak Usia 1-4 Tahun

\begin{tabular}{|c|c|c|c|c|c|c|c|c|c|}
\hline \multirow{3}{*}{$\begin{array}{l}\text { Kebiasaan Merokok } \\
\text { di Dalam Rumah }\end{array}$} & \multicolumn{6}{|c|}{ Kejadian pneumonia } & \multirow{2}{*}{\multicolumn{2}{|c|}{ Jumlah }} & \multirow{3}{*}{$P$ value } \\
\hline & \multicolumn{2}{|c|}{ Pneumonia } & \multicolumn{2}{|c|}{ Berat } & \multicolumn{2}{|c|}{ Sangat berat } & & & \\
\hline & $\mathrm{n}$ & $\%$ & $\mathrm{n}$ & $\%$ & $\mathrm{n}$ & $\%$ & $\mathrm{n}$ & $\%$ & \\
\hline Tidak ada & 34 & 100 & 0 & 0 & 0 & 0 & 34 & 100 & \multirow{2}{*}{0.016} \\
\hline Ada & 41 & 78.8 & 7 & 13.5 & 4 & 7.7 & 52 & 100 & \\
\hline Total & 75 & 87.2 & 7 & 8.1 & 4 & 4.7 & 86 & 100 & \\
\hline
\end{tabular}

\section{PEMBAHASAN}

Hasil penelitian mengenai karekteristik responden menunjukkan bahwa sebagian besar pendidikan orang tua adalah tamatan SD sebanyak 72 (83,72\%). Rendahnya tingkat pendidikan orang tua dapat menentukan tingkat pengetahuan dan perilaku. Pengetahuan atau kognitif merupakan domain yang sangat penting dalam membentuk tindakan seseorang atau over behavior (Notoatmodjo, 2014). Sehingga kemungkinan besar tingkat pengetahuan orang tua tentang bahaya rokok terhadap pneumonia juga rendah.

Berdasarkan jenis kelamin anak, menunjukkan bahwa laki-laki lebih banyak dibandingkan dengan anak perempuan sebanyak 46 (53,49\%). Anak dengan jenis kelamin laki-laki lebih berisiko terserang pneumonia dibandingkan dengan anak dengan jenis kelamin perempuan. Hal ini disebabkan karena pada diameter saluran pernafasan anak laki-laki lebih kecil dibandingkan dengan anak perempuan atau adanya perbedaan dalam daya tahan tubuh anak laki-laki dan perempuan (Astuti, 2010).

Dari karakteristik usia diperoleh bahwa lebih dari setengahnya anak berusia 1 tahun sebanyak $54(62,79)$. Pneumonia pada balita paling sering disebabkan oleh virus pernafasan (Respiratory Syncytial Virus, adenovirus, virus parainfluenza, virus influenza) dan puncaknya terjadi pada usia 2-3 tahun (Oktaviani, 2018).

Terdapat hubungan kebiasaan merokok di dalam rumah dengan kejadian Pneumonia pada anak usia 1-4 tahun di wilayah kerja UPTD Puskesmas Mundu Kabupaten Cirebon Tahun 2020. Pada analisis bivariat dalam penelitian ini, didapat hasil uji statistik dengan Chi Square didapatkan $p$ value $=0,016$ $(<0,05)$. Hasil penelitian yang diperoleh terdapat 34 anak usia 1-4 tahun (balita) yang mengalami pneumonia walaupun anggota tidak memiliki anggota keluarga yang merokok di dalam rumah. Hal ini mungkin dapat terjadi ketika orangtua merokok di luar rumah tetapi pada saat masuk rumah mereka langsung menggendong balita tanpa mengganti pakaian terlebih dahulu sehingga asap rokok yang masih menempel di pakaian terhisap oleh balita tersebut.

Hasil penelitian ini sejalan dengan hasil penelitian Almer Aprilioza, Dadi S Argadireza, Yudi Feriandi yang berjudul "Hubungan Kebiasaan Merokok Pada Orang Tua Dengan Kejadian Pneumonia Pada Balita Di Wilayah Kerja Puskesmas Plered" dari 84 balita terdapat 43 balita yang mengalami Pneumonia 
dengan orang tua yang memiliki kebiasaan merokok $(95,6 \%)$ dan 2 balita dengan orang tua yang tidak memiliki kebiasaan merokok $(4,4 \%)$. Balita yang tidak mengalami Pneumonia berjumlah 32 balita yang memiliki orang tua dengan kebiasaan merokok $(82,1 \%)$ dan 7 balita dengan orang tua yang tidak memiliki kebiasaan merokok (19,9\%). Hasil penelitian menunjukkan terdapat hubungan kebiasaan merokok orang tua dengan kejadian pada balita (Aprilioza, Almer. Argadireza, Dadi S. Feriandi, 2015).

Hasil penelitian Rony Darmansyah A, Djauhar Ismail, dan Retna Siwi P yang berjudul "Kebiasaan Merokok Keluarga Serumah Dan Kejadian Pneumonia Pada Balita Di Bantul Tahun 2017". Hasil penelitiannya menunjukan bahwa terdapat hubungan kebiasaan merokok serumah dengan kejadian pneumonia pada balita dengan nilai $p 0,020$. (Alnur, Rony $D$. IsImail, Djauhar; Padmawati, 2017).

Berdasarkan penelitian Yuwono, penelitian tersebut menunjukkan bahwa risiko balita terkena Pneumonia akan meningkat jika tinggal di rumah yang penghuninya memiliki kebiasaan merokok. Asap rokok bukan menjadi penyebab langsung kejadian Pneumonia pada balita, tetapi menjadi faktor tidak langsung yang diantaranya dapat menimbulkan penyakit paru-paru yang akan melemahkan daya tahan tubuh balita(KP3B, 2017)

Klasifikasi dan gejala klinis pneumonia menurut WHO adalah (1) bukan pneumonia; tidak ada sesak napas, (2) pneumonia; napas cepat, tidak ada tarikan pada dinding dada, (3) pneumonia berat; napas cepat, ada tariakan pada dinding dada, tidak ada sianosis, (4) pneumonia sangat berat; napas cepat, ada tariakan pada dinding dada, terdapat sianosis, kejang, tidak mampu makan/minum, gizi buruk(Ditjen P2PL, 2012).

Rokok memiliki dampak terhadap perokok pasif berupa gangguan pernafasan, serangan jantung, kanker paru, dan kematian dini. Merokok di dekat bayi atau anak-anak berusia 2 minggu - 1 tahun berbahaya, sebab jika bayi atau anak-anak menghirup asap rokok yang dihembuskan bahkan hingga sampai menjadi perokok pasif akibat seringnya menghirup asap rokok, mereka berisiko mengalami SIDS (Sudden Infant Death Syndrome) yakni kematian bayi secara mendadak $(H$. Tandra, 2013).

Asumsi peneliti, banyaknya orang yang memiliki kebiasaan merokok di dalam rumah yang sulit untuk dirubah, sehingga ini berdampak besar bagi kesehatan anak. Masalah yang sering terjadi pada anak akibat adanya orang yang merokok di dalam rumah yaitu terganggunya sistem pernapasan seperti Pneumonia.

Pada umumnya Pneumonia ini disebabkan oleh bakteri, akan tetapi banyak juga faktor yang berpengaruh terhadap terjadinya pneumonia pada anak yaitu faktor lingkungan seperti kualitas udara dalam rumah, ventilasi, kepadatan hunian. Obat nyamuk bakar, jendela rumah, suhu dan kelembaban. Sedangkan dari faktor individu anak yaitu jenis kelamin, berat badan lahir, status gizi, dan pemberian ASI eksklusif (Purnamasari, 2012)(Kartasasmita; B, 2010)(Hartati, 2011)(Peraturan Menteri Kesehatan No. 1077 Tentang Penyehatan Udara Dalam Ruang Rumah, 2011)(Astuti; Harwina W ; Rahmat Angga., 2010).

\section{KESIMPULAN DAN SARAN}

Terdapat hubungan kebiasaan merokok di dalam rumah dengan kejadian Pneumonia pada anak usia 1-4 tahun di wilayah kerja UPTD Puskesmas Mundu tahun 2020. Petugas kesehatan diharapkan dapat meningkatkan pemberian informasi tentang kebiasaan merokok dan dampak dari kebiasaan merokok, terutama merokok di dalam rumah seperti poster atau spanduk yang dipasang di tempattempat umum.

\section{REFERENSI}

Alnur, Rony D. Islmail, Djauhar; Padmawati, R. S. (2017). Kebiasaan Merokok Keluarga Serumah Dan Kejadian Pneumonia Pada Balita Di Bantul Tahun 2015. Journal of Community Medicine and Public Health, 33(3), 119-124.

Aprilioza, Almer. Argadireza, Dadi S. Feriandi, Y. (2015). Hubungan Kebiasaan Merokok Pada Orang Tua Dengan Kejadian Pneumonia Pada Balita Di Wilayah Kerja Puskesmas Plered. Prosiding Pendidikan Dokter, 325-328.

Astuti; Harwina W; Rahmat Angga. (2010). Asuhan 
Keperawatan Anak Dengan Gangguan Sistem Pernapasan. Trans Info Media.

Ditjen P2PL. (2012). Modul Tatalaksana Standar Pneumonia. Depkes RI.

H. Tandra. (2013). Merokok dan Kesehatan. http//www.antirokok.or.id/berita-berita-rokokkesehatan.htm.

Hartati, S. (2011). Analisis Faktor Risiko yang Berhubungan dengan Kejadian Pneumonia Pada Anak Balita di RSUD Pasar Rebo Jakarta. UI.

Hidayat, A. (2013). Metode Penelitian Keperawatan Dan Teknik Analisis Data. Salemba Medika. Salemba Medika.

Kartasasmita; B, C. (2010). Pneumonia Pembunuh Balita. Buletin Jendela Epidemiologi, 22-26.

Kemenkes, R. (2013). Perilaku Merokok Masyarakat Indonesia. Pusat Data Dan Informasi Kementerian Kesehatan

$R I$. file://C:/Users/user/Downloads/Documents/infodat in-hari-tanpa-tembakau-sedunia.pdf

Kemenkes, R. (2018a). Riset Kesehatan Dasar. www.kesmas.kemkes.go.id

Kemenkes, R. (2018b). Situasi Umum Konsumsi Tembakau di Indonesia. Pusat Data Dan Informasi Kementerian Kesehatan RI. file:///C:/Users/user/Downloads/Documents/infodat in tembakau per halaman.pdf

Peraturan Menteri Kesehatan No. 1077 Tentang Penyehatan Udara Dalam Ruang Rumah, (2011).

KP3B. (2017). Pengertian Merokok Dan Akibatnya.
https://dinkes.bantenprov.go.id/read/berita/488/PE NGERTIAN-MEROKOK-DAN-AKIBATNYA.html Notoatmodjo, S. (2014). Ilmu Perilaku dan Kesehatan.

Oktaviani, S. (2018). Hubungan Paparan Asap Rokok Dan Rumah Tidak Sehat Dengan Kejadian Pneumonia Pada Anak Balita Di Puskesmas wirobrajan yogyakarta tahun 2015. The Indonesian Journal Public Health, 13(01), 119129.

P2P. (2019). Rekap Laporan Pengendalian ISPA Kabupaten Cirebon.

Purnamasari, E. R. W. (2012). Pengaruh Pendidikan Kesehatan Pada Orangtua Terhadap Pengetahuan dan Kepatuhan Kunjungan Ulang Balita dengan Pneumonia di Puskesmas Kecamatan Pasar Minggu. UI.

Puspita, R. (2015). Gambaran Karakterisitik Kejadian Pneumonia Pada Balita Di Puskesmas Wanandadi Kabupaten Banjarnegara Tahun 2014. Jurnal IImiah Medains, 1(1).

Putri, A. F. I. (2017). Hubungan Antara Keberadaan Anggota Keluarga Yang Merokok Dengan Kejadian Pneumonia Pada Anak Usia 1-4 Tahun Di Wilayah kerja UPTD Puskesmas Tawangsari Sukoharjo Tahun 2014. Universitas Muhammadiyah Surakarta.

Sugiyono. (2016). Metode Penelitian Kuantitatif Dan Kualitatif. Alfabeta. 